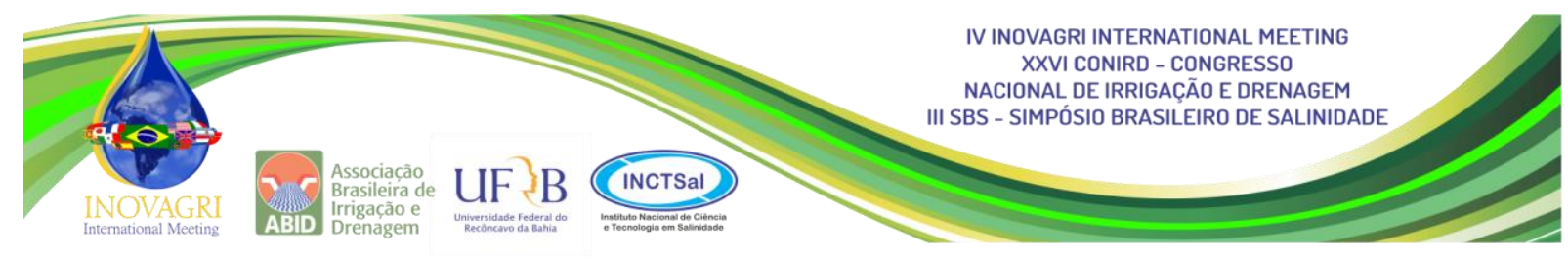

\title{
CAPACITIVE PROBE CALIBRATION IN EUTROFERRIC RED NITOSOL CULTIVATED WITH IRRIGATED FORAGES
}

\author{
A. C. Sanches ${ }^{1}$, D.P. Souza ${ }^{2}$, F. L. F. de Jesus ${ }^{3}$, R. G. Maffei ${ }^{4}$, F. C. Mendonça ${ }^{5}$,
} J. R. M. Pezzopane ${ }^{6}$

\begin{abstract}
Knowledge of soil water content is important for proper irrigation management because it allows estimating the required amount of water to be applied at the correct time. Capacitance sensors are an alternative of quantification of soil water content $\left(\Theta, \mathrm{cm}^{3} \mathrm{~cm}^{-3}\right)$, providing depth readings in a practical and fast way. A capacitive probe (Diviner $2000^{\circledR}$ ) was calibrated in a eutroferric red nitosol cultivated with irrigated forages at the experimental area of ESALQ/USP in the city of Piracicaba - SP, Brazil. Four access tubes were installed and every 2 weeks samples were collected with 3 replicates for each depth level, by the end of 8 weeks starting

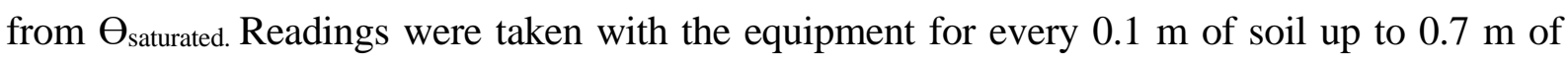
depth, together with the collection of soil samples for the determination of $\Theta$ in the laboratory. A power equation was developed for each depth studied as well as for the whole soil profile. The proposed general calibration curve $\left(\mathrm{SF}=0,256^{*} \Theta_{\text {current }}{ }^{0.3422}\right)$, adjusted by regression analysis, was significantly related to the measurements of the equipment, with high correlation $\left(r^{2}=0.87\right)$, and standard error of $0.022 \mathrm{~cm}^{3} \mathrm{~cm}^{-3}$. The calibration for each depth has shown higher coefficients of correlation at the lower depths, minimizing the error of the estimates. On-site calibration allowed better accuracy of soil water monitoring and, thus, provide better irrigation management.
\end{abstract}

KEY WORDS: sensor, irrigation management, soil moisture, frequency domain reflectometry.

\section{CALIBRAÇÃO DE SONDA CAPACITIVA EM NITOSSOLO VERMELHO LATOSSÓLICO EUTROFÉRRICO CULTIVADO COM FORRAGEIRAS IRRIGADAS}

\footnotetext{
${ }^{1}$ Agronomist, doctor student in Agricultural Systems Engineering, ESALQ/USP arthur_carniato@ hotmail.com

${ }^{2}$ Doctor student in Agricultural Systems Engineering, ESALQ/USP, dpdsouza@usp.br

${ }^{3}$ Doctor student in Agricultural Systems Engineering, ESALQ/USP, fernandalamede@usp.br

${ }^{4}$ Graduating in Agronomist, ESALQ/USP, rodolfo.maffei@usp.br

${ }^{5}$ Doctor professor, Department of Biosystems Engineering - ESALQ/USP, fernandomendonca@usp.br

${ }^{6}$ Researcher Doctor, EMBRAPA, jose.pezzopane@embrapa.br
} 
RESUMO: O conhecimento do teor de água no solo é importante para o manejo adequado da irrigação, pois permite estimar a quantidade necessária de água a ser aplicada no tempo correto. Sensores de capacitância é uma alternativa de quantificação do teor de água do solo $\left(\Theta, \mathrm{m}^{3}\right.$ $\mathrm{m}^{-3}$ ), provendo leituras em profundidade de forma prática e rápida. Uma sonda capacitiva (Diviner $2000^{\circledR}$ ) foi calibrada em um Nitossolo Vermelho Eutroférrico latossólico cultivado com forrageiras tropicais na área experimental da ESALQ/USP na cidade de Piracicaba - SP, Brasil. Quatro tubos de acesso foram instalados e a cada 2 semanas foram coletadas amostras com 3 repetições para cada nível de profundidade, até ao final de 8 semanas, partindo do $\Theta_{\text {saturado. }}$ Efetuaram-se leituras com o equipamento para cada $0.1 \mathrm{~m}$ de solo até $0,7 \mathrm{~m}$ de profundidade, juntamente com a coleta das amostras de solo para a determinação de $\Theta$ em laboratório. Uma equação de potência foi desenvolvida para cada profundidade estudada como também para o todo perfil do solo. A curva geral de calibração proposta $\left(\mathrm{SF}=0,256^{*} \Theta_{\text {atual }}{ }^{0,3422}\right)$, ajustada por análise de regressão, foi significativamente relacionada com as medidas do equipamento, com alta correlação $\left(r^{2}=0,87\right)$ e erro-padrão de $0,022 \mathrm{~cm}^{3} \mathrm{~cm}^{-3}$. A calibração para cada profundidade tem mostrado maiores coeficientes de correlação nas profundidades menores, minimizando o erro das estimativas. A calibração feita no local permitiu melhor acurácia do monitoramento da água no solo e assim, proporcionar um melhor manejo da irrigação.

PALAVRAS-CHAVE: sensor, manejo da irrigação, umidade do solo, reflectometria no domínio da frequência.

\section{INTRODUCTION}

Soil and especially water are extremely important for agricultural production and their rational management is determinant for the development of the plants (Cremon et al., 2014), as in other crops, good pasture management requires the monitoring of the Soil water content, which is an extremely variable parameter, mainly with time, influenced by rainfall, irrigation, drainage or by evaporation and other crop management practices (SOUZA et al., 2016). Thus, maintaining soil water content suitable for plant development is difficult without real-time monitoring (RAMOS et al., 2014). The water content in the soil can be obtained through direct and indirect methods (PRIMO et al., 2015). In the direct method, gravimetric is the standard, being accurate and low cost. However, it is destructive and cannot be automated, making it poorly suited to monitoring (SOUZA et al., 2016). Among the indirect methods, we have the 
tensiometry, which presents low cost of installation and simple handling, besides this, in the last years the methods of TDR (Reflectometry in the Domain of Time) and the FDR (Frequency Domain Reflectometry) have stood out By the accuracy of the data (SOUZA et al., 2013, 2016, RAMOS et al., 2014, PRIMO et al., 2015).

Studies of the different methods become fundamental, considering the growing concern about water scarcity and the need for both water and energy savings (SOUZA et al., 2013, ABDOULKADER et al., 2015). Not only for these reasons, but also because of increased competition in order to maximize productivity in the field (Haberland et al., 2015).

In the TDR method, the soil permittivity is related to water by measuring the propagation velocity of an electromagnetic signal carried on a transmission line fixed to the ground. In contrast, the FDR determines the volumetric water content in the soil by measuring the resonance frequency, which changes with the apparent permittivity of the soil (TEDESCHI et al., 2014).

However, the Diviner ${ }^{\circledR}$ (FDR) sensor, because it has the mobile probe, can be used in several places for handling of irrigation. In addition, the information in the literature makes clear the calibration requirements for each type of moisture sensor, as well as for its application and use in different types of soil (GAVA; DA SILVA; BAIO, 2016).

In order to evaluate the performance of the FDR Diviner® probe in several types of soil, it has been gaining importance at a time of its increasing use in the evaluation of the water consumption of several crops (Oliveira et al. (1998), which is based on the results obtained in the literature.

Thus, the objective of this work was to calibrate the probe Diviner $2000^{\circledR}$ Sentek probe in an eutroferric red nitosol cultivated with irrigated forages in Piracicaba, Brazil.

\section{MATERIAL AND METHODS}

The study was conducted at the University of São Paulo at the "Luiz de Queiroz" School of Agriculture (ESALQ / USP), in the experimental area of the campus (Latitude $22^{\circ} 42$ 'South and Longitude $47^{\circ} 38^{\prime}$ ) and at the Laboratory of Soil and Water Quality in the Department of Engineering of Biosystems of ESALQ / USP.

In October of 2015, soil rings were collected to characterize the water retention curve in soil and its density. The soil samples were collected for chemical characterization and granulometric characterization (Figure 1), being classified as eutroferric red nitosol nitosol (SANTOS et al., 2013). 


\section{TABLE 1}

For calibration of the FRD Diviner $2000 ®$ probe, 4 access tubes from the manufacturer Sentek technologies ${ }^{\circledR}$ previously installed in February 2016 were used. Each PVC access tube (polyvinyl chloride) was $1.0 \mathrm{~m}$ long, $51 \mathrm{~mm}$ of diameter, thickness of $5.5 \mathrm{~mm}$, randomly installed in the area to the useful depth of $0.7 \mathrm{~m}$, using a completely randomized design (Figure $1)$.

\section{FIGURE 1}

Samples of soil samples for calibration occurred between April and May 2016. Five days of separate collections were used on a 8-day time scale (interval between collections). Samples of deformed soil samples were collected for each soil depth to determine the current moisture (Өa) in the 4 replicates of tubes, according to Andrade Júnior et al. (2007). It used 7 depths, being 0-10 cm, $10-20 \mathrm{~cm}, 20-30 \mathrm{~cm}, 30-40 \mathrm{~cm}, 40-50 \mathrm{~cm}, 50-60 \mathrm{~cm}$ and $60-70 \mathrm{~cm}$.

The first 3 sampling dates were performed with low soil moisture (as close as possible to the wilting point), which was covered with plastic canvas and did not rain for approximately 20 days. The first sampling took place on April 14, 2016, the second 8 days after the first and the third 16 days after the first, in order to characterize the dryest soil profile. After these samples, the soil was saturated with water and a sample was collected by depth and by repetition, 2 days after saturation of the soil profile, the next one being performed 8 days after the same. In this way, a good variation of the volumetric content of water in the soil could be obtained.

At the time of soil sampling at different depths, data were scanned with the FDR sensor at all depths, for further comparison between the relative frequency domain (FDR) and soil moisture $(\Theta)$ data. The soil samples were stored in collection pots and later placed in a thermal box to avoid water loss through evaporation. They were then taken to the Laboratory of Soils and Water Quality, where moisture was determined based on weight $\left(\mathrm{U}, \mathrm{g} \mathrm{g}^{-1}\right)$, and later converted to moisture based on volume $\left(\Theta, \mathrm{cm}^{3} \mathrm{~cm}^{-3}\right)$, using the global soil density ( $\mathrm{dg}$, in $\mathrm{g}$ $\mathrm{cm}^{-3}$ ) previously characterized with the collection of undisturbed samples.

Thus, volumetric moisture was calibrated with the relative frequency (EF) scale data, defined by the equation (SENTEK, 2000):

$$
\mathrm{EF}=\frac{\left(\mathrm{F}_{\mathrm{a}}-\mathrm{F}_{\mathrm{s}}\right)}{\left(\mathrm{F}_{\mathrm{a}}-\mathrm{F}_{\mathrm{w}}\right)}
$$

Where;

$\mathrm{Fa}$ - Reading the frequency in the PVC tube totally suspended in the air;

Fs - Frequency reading on the PVC tube in the ground;

$\mathrm{Fw}$ - Frequency reading on sealed and immersed PVC tube. 
After the collection period, the data obtained were compared using scatter plot and correlation coefficient $\left(\mathrm{R}^{2}\right)$, by means of potential adjustment of the data.

\section{RESULTS AND DISCUSSION}

The calibrations obtained presented adjustments with high correction values (Table 2) between the pairs of volumetric humidity values $(\Theta)$ versus the frequency scale (EF). The calibrations showed an average standard deviation of $1.8 \mathrm{~cm}^{3} \mathrm{~cm}-3$ in relation to the manufacturer's standard $(\mathrm{EF}=0.2746 * \Theta \mathrm{a} 0.3314 ; \mathrm{R} 2=0.99)$, however, the manufacturer determined only a mean curve combining Soil textures that can be applied in general to irrigation management.

\section{TABLE 2}

The variation of the coefficient of determination between the layers is a common thing in the searches with calibrations of FDR probe, varying in average of 0.8 to 0.99 (SOUZA et al., 2013; RAMOS et al., 2014; TEDESCHI et al. (1998), which is based on the results obtained in the literature. As in the work, Haberland et al. (2015) observed that the standard error modifies according to the depth, being that in its work, it increased in depth, negatively influencing the $\mathrm{R}^{2}$ obtaining a value of 0.59 in the deepest layer of $60 \mathrm{~cm}$.

The soil studied has a high concentration of clay which increases in depth to more than $50 \%$ according to Table 1, the clay can directly influence the soil moisture in FDR probe calibration work conducted in soil with high concentration of clay varying From 54 to $79 \%$, the total pore volume was negatively correlated with the soil moisture content (BÖHME; BECKER; DIEKKRÜGER, 2013), which may explain this negative variation of the correlation coefficients in depth due to increased clay concentration.

For Gava et al., (2016) the humidity sensors behave differently among soil types, being able to record readings above or below the actual measurements, according to the author in his work the fact that the soil is sandy may have contributed so as not to present soil moisture reading problems with the HidroFarm equipment. Already, Primo et al. (2015) states that the variations between the calibration curves of his work with the FDR Diviner® probe is due to variability of the apparent bulk density values.

The mean calibration curve with the data of the different depths presented an adjustment with high coefficient of correlation (Figure 2). When compared to the curve presented by the manufacturer, it presented a standard deviation in relation to the same one of $1,79 \mathrm{~cm}^{3} \mathrm{~cm}^{-3}$ with 
a variation of up to $3,19 \mathrm{~cm}^{3} \mathrm{~cm}^{-3}$. This represents a greater moisture spectrum relative to the manufacturer, readily exceeding $40 \%$ humidity above 0.9 of the frequency range.

\section{FIGURE 2}

When all data of all depths were used to obtain calibration for the soil profile, the error remained low with $\mathrm{R}^{2}=0.87$. Souza et al. (2013) obtained high mean correlation coefficients above 0.9 with medium clay soils. Already, in a study by Silva Junior et al. (2013), that using a soil profile up to $1.0 \mathrm{~m}$ obtained a unique calibration equation with $\mathrm{R}^{2}=0.212$ showing many dispersed measurements.

It is possible to note that the errors have been larger in depth, as has been observed in other studies with FDR increasing the error in depth (SILVA JUNIOR et al., 2013, HABERLAND et al., 2015), evidencing such limitation in the use associated with Installation problems and tube defects to the soil including verticality (CURTO et al., 2016).

\section{CONCLUSIONS}

- The FDR probe proved to be adequate to obtain soil water in eutroferric red nitosol.

- The calibrations showed an increase in the standard error of the estimate at intermediate depths with a decrease in the coefficient of determination of the calibration.

- The standard deviation presented in the calibrations was small in relation to the calibration of the manufacturer, and it can be used for the management of this soil.

- For more precise adjustments, local calibration is required for use of the FDR probe.

\section{ACKNOWLEDGEMENTS}

FAPESP for the financing of the project and CAPES / CNPQ for the aid granted through a doctorate scholarship to the first author.

\section{REFERENCES}

ABDOULKADER, B. A.; MOHAMED, B.; NABIL, M.; ALAOUI-SOSSÉ, B.; ERIC, C.; ALEYA, L. Wastewater use in agriculture in Djibouti: Effectiveness of sand filtration treatments and impact of wastewater irrigation on growth and yield of Panicum maximum. Ecological Engineering, v. 84, p. 607-614, 2015. 
ANDRADE JÚNIOR, A. S.; SILVA, C. R.; DANIEL, R. Calibração de um sensor capacitivo de umidade em Latossolo amarelo na microrregião do litoral Piauiense. Agrária, v. 2, p. 303 307, 2007.

BÖHME, B.; BECKER, M.; DIEKKRÜGER, B. Calibrating a FDR sensor for soil moisture monitoring in a wetland in Central Kenya. Physics and Chemistry of the Earth, v. 66, p. 101$111,2013$.

CREMON, C.; LONGO, L.; MAPELI, N. C.; SILVA, L. A. M.; SILVA, W. M. da. Determinação da umidade de diferentes solos do Pantanal Matogrossense via micro-ondas e método padrão. Revista Agrarian, v. 7, n. 24, p. 280-288, 2014.

CURTO, L.; COVI, M.; GASSMANN, M. I.; CAMBARERI, M.; MAGGIORA, A. Della. Calibración de datos observados de contenido de agua en el suelo con sensores capacitivos. Meteorologica, v. 41, n. 2, p. 49-63, 2016.

FERREIRA, V. M.; KLAR, A. E.; JÚNIOR, A. S. A.; BASTOS, E. A.; OLIVEIRA, S. R. M. Evapotranspiração e coefciente de cultura da melancia na microrregião de Teresina, PI, Brasil. Comunicata Scientiae, v. 6, n. 4, p. 488-494, 2015.

GAVA, R.; DA SILVA, E. E.; BAIO, F. H. R. Calibração De Sensor Eletrônico De Umidade Em Diferentes Texturas De Solo. Revista Brasileira de Engenharia de Biossistemas, v. 10, n. 2, p. 154-162, 2016.

HABERLAND, J.; GÁLVEZ, R.; KREMER, C.; ZUÑIGA, C.; RUDOLFFI, Y. Accurate soil water content monitoring in real time with appropriate field calibration of the fdr device " diviner $2000 "$ in a commercial table grape vineyard. International Journal of Science Environment and Technology, v. 4, n. 2, p. 273-284, 2015.

NASCIMENTO, F. N.; BASTOS, E. A.; CARDOSO, M. J.; ANDRADE JÚNIOR, A. S.; RIBEIRO, V. Q. Parâmetros Fisiológicos e Produtividade de Espigas Verdes de Milho sob Diferentes Lâminas de Irrigação. Revista Brasileira de Milho e Sorgo, v. 14, n. 2, p. 167-181, 2015.

OLIVEIRA, S. R. M. de; ANDRADE JÚNIOR, A. S. de; RIBEIRO, J. L.; BARROS, M. A. Coeficientes de cultura do algodão herbáceo e do feijão-caupi em sistemas monocultivo e consorciado. Revista Brasileira de Agricultura Irrigada, v. 7, n. 3, p. 191-200, 2013.

PEREIRA, M. T. J.; SILVA, T. J. A. da; BONFIM-SILVA, E. M.; PEREIRA, M. T. J.; SILVA, T. J. A. da; BONFIM-SILVA, E. M. Soil water content and wood ash fertilization on the 
cultivation of gladiolus. Revista Brasileira de Engenharia Agrícola e Ambiental, v. 20, n. 4, p. $350-356$, abr. 2016.

PRIMO, J. T. de A.; SILVA, T. G. F. da; SILVA, S. M. S. e; MOURA, M. S. B. de; SOUZA, L. S. B. de. Calibração de sondas capacitivas, funções físico-Hídricas e variação do armazenamento de água em um argissolo cultivado com palma forrageira. Revista Ceres, v. 62, n. 1, p. 20-29, 2015.

RAMOS, F. T.; PIVETTA, F.; DE MATOS, V. A. T.; SEIXAS, G. de B.; CAMPELO JÚNIOR, J. H. Acurácia e calibração de uma sonda de capacitância em um neossolo quartzarênico cultivado com caju. Bioscience Journal, v. 30, n. 6, p. 1631-1641, 2014.

SANTOS, H. G. dos; JACOMINE, P. K. T.; ANJOS, L. H. C. dos; OLIVEIRA, V. Á. D.; LUMBRERAS, J. F.; COELHO, M. R.; AALMEIDA, J. A. de.; CUNHA, T. J. F.; OLIVEIRA, J. B. de. Sistema brasileiro de classificação de solos. 3. ed. Brasília-DF: Embrapa, 2013.

SIlVA JUNIOR, J. J. da; COLOMBO, A.; SCALCO, M. S.; SILVA, B. M.; LIMA, P. T. Calibração de sondas de capacitância para determinação de umidade em latossolo vermelho distroférrico. Irriga, v. 18, n. 4, p. 743-755, 2013.

SOUZA, C. F.; PIRES, R. C. M.; MIRANDA, D. B. de; VARALLO, A. C. T. Calibração de sondas FDR e TDR para a estimativa da umidade em dois tipos de solo. Irriga, v. 18, n. 4, p. 597-606, 2013.

SOUZA, C. F.; SILVA, C. R. da; JÚNIOR, A. S. de A.; COELHO, E. F. Monitoramento do teor de água no solo em tempo real com as técnicas de TDR e FDR. Irriga, v. Edição Esp, n. Irrigação, p. 26-42, 2016.

SOUZA, L. S. B. DE; MOURA, M. S. B. DE; SEDIYAMA, G. C.; SILVA, T. G.. Requerimento hídrico e coeficiente de cultura do milho e feijão-caupi em sistemas exclusivo e consorciado. Revista Caatinga, v. 28, n. 4, p. 151-160, dez. 2015.

TEDESCHI, A.; HUANG, C. H.; ZONG, L.; YOU, Q. G.; XUE, X. Calibration equations for Diviner 2000 capacitance measurements of volumetric soil water content in salt-affected soils. Soil Research, v. 52, n. 4, p. 379-387, 2014. 
Table 1. Chemical and granulometric analysis of the soil of the experimental area in the $0-20 \mathrm{~cm}$ layer, $20-40 \mathrm{~cm}$. Piracicaba / SP, 2015.

\begin{tabular}{|c|c|c|c|c|c|c|c|c|c|c|c|}
\hline $\begin{array}{l}\text { Layer } \\
(\mathrm{cm})\end{array}$ & $\begin{array}{c}\mathrm{pH} \\
\mathrm{CaCl}_{2}\end{array}$ & $\begin{array}{c}\mathrm{P} \\
\mathrm{mg} \mathrm{dm^{-3 }}\end{array}$ & $\mathrm{K}$ & $\mathrm{Ca}$ & $\begin{array}{l}\mathrm{Mg} \\
\mathrm{mol}_{\mathrm{c}} \mathrm{C}\end{array}$ & $+\mathrm{Al}$ & & $\begin{array}{c}\text { CTC } \\
\mathrm{cmol}_{\mathrm{c}} \mathrm{dm}^{-3}\end{array}$ & $\begin{array}{l}\text { Sand } \\
(\%)\end{array}$ & $\begin{array}{l}\text { Silt } \\
(\%)\end{array}$ & $\begin{array}{l}\text { Clay } \\
(\%)\end{array}$ \\
\hline $0-20$ & 5.3 & 72 & 0.94 & 3.9 & 1.8 & 3.1 & 0.2 & 9.74 & 35.7 & 19.2 & 45.1 \\
\hline $20-40$ & 4.9 & 31 & 0.44 & 1.3 & 1.0 & 4.2 & 0.2 & 6.94 & 29.3 & 18.7 & 52.0 \\
\hline
\end{tabular}

$\mathrm{P}=$ phosphorus; $\mathrm{K}$ = potassium; $\mathrm{Ca}=$ calcium; $\mathrm{Mg}$ = magnesium; $\mathrm{H}+\mathrm{Al}=$ potential acidity; $\mathrm{Al}=$ exchangeable aluminum; $\mathrm{CTC}=$ cation exchange complex

Table 2. Diviner $2000^{\circledR}$ probe calibration equations for each layer and standard error of estimation (EPE) with respect to the manufacturer. Piracicaba-SP, 2016.

\begin{tabular}{|c|c|c|c|c|c|c|}
\hline \multirow[b]{2}{*}{ Layers $(\mathrm{cm})$} & \multirow[b]{2}{*}{ Eq. of calibration } & \multirow[b]{2}{*}{$\mathrm{R}^{2}$} & \multirow[b]{2}{*}{ EPE* $^{*}$} & \multirow[b]{2}{*}{$\mathrm{N}^{* *}$} & \multicolumn{2}{|c|}{ Humidity $^{* * *}\left(\mathrm{~cm}^{3} \mathrm{~cm}^{-3}\right)$} \\
\hline & & & & & Minimum & Maximum \\
\hline $0-10$ & $\mathrm{EF}=0.2723 * \Theta_{\mathrm{a}}{ }^{0.3324}$ & 0,96 & 0,24 & 20 & 11.26 & 37.67 \\
\hline $10-20$ & $\mathrm{EF}=0.15^{*} \Theta_{\mathrm{a}}^{0.4992}$ & 0,90 & 0,43 & 20 & 15.30 & 38.75 \\
\hline $20-30$ & $\mathrm{EF}=0.2657 * \Theta_{\mathrm{a}}{ }^{0.345}$ & 0,99 & 0,18 & 20 & 10.09 & 39.05 \\
\hline $30-40$ & $\mathrm{EF}=0.1045 * \Theta_{\mathrm{a}}^{0.5995}$ & 0,89 & 0,51 & 20 & 17.84 & 39.33 \\
\hline $40-50$ & $\mathrm{EF}=0.3835 * \Theta_{\mathrm{a}}^{0.225}$ & 0,81 & 0,55 & 20 & 30.17 & 46.43 \\
\hline $50-60$ & $\mathrm{EF}=0.2044 * \Theta^{0.4095}$ & 0,84 & 0,37 & 20 & 29.41 & 45.74 \\
\hline $60-70$ & $\mathrm{EF}=0.1746^{*} \Theta_{\mathrm{a}}^{0.4486}$ & 0,91 & 0,38 & 20 & 32.12 & 43.77 \\
\hline
\end{tabular}

* Standard error of estimate $\left( \pm \mathrm{cm}^{3} \mathrm{~cm}^{-3}\right), * *$ Number of sample data, *** Humidity achieved in the field

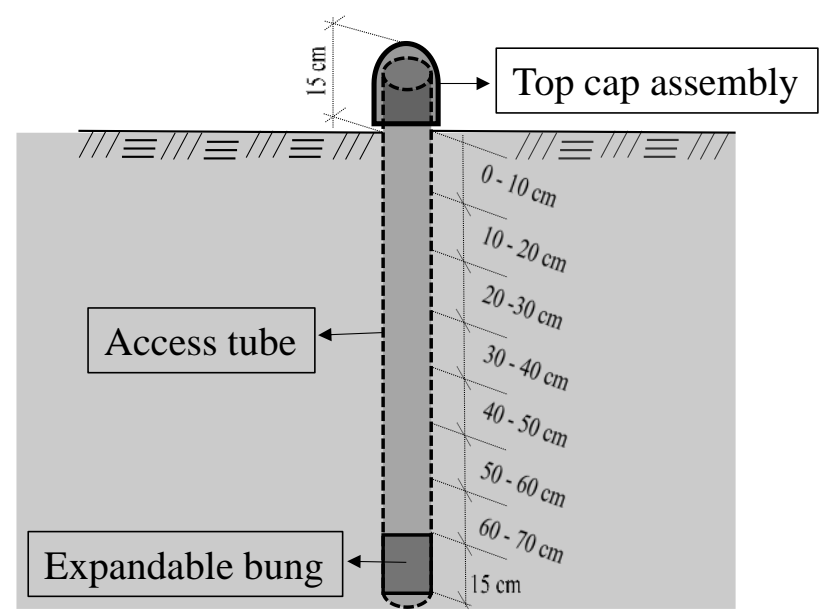

Figure 1. Installation of the access tubes in the experimental area. Piracicaba, SP, 2016. 
A. C. Sanches et al.

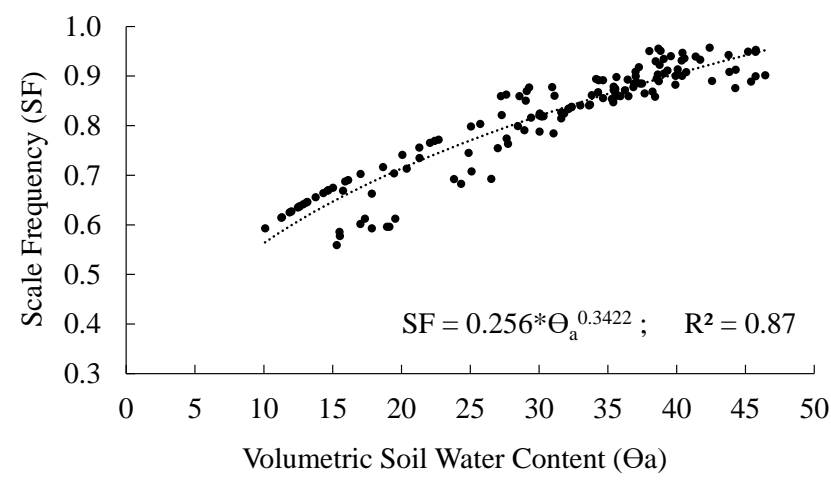

Figure 2. Mean calibration curve of the FDR Diviner $2000^{\circledR}$ probe. Piracicaba, 2016. 